\section{Trade makes sense}

Against the odds, last week's meeting of the trading nations reached a hopeful agreement.

THE General Agreement on Tariffs and Trade (GATT) is not so much a treaty whose violations lead nations to declare war on each other as a kind of bargain which is repeatedly broken by nations large and small, but which miraculously has not yet been so flagrantly violated as to be torn up. On the contrary, GATT and its consequences have helped us all survive the long recession of the past decade. While economic growth has been stagnant in most places and almost stagnant even in Japan, the growth of world trade has been spectacular, roughly 7 per cent a year.

This steady trend has been more than merely an exercise in accountancy in which some countries have been able to pay for imports they could not otherwise have afforded. Rather, it is a sign that, even on an international scale, there is still substance in Adam Smith's great dream of an efficient (or economic) "division of labour" in which people concentrate on doing what they do best, selling the product of their labour to others and spending the proceeds on the products of other specialists' labours. While the prosperity of nineteenth century Britain was a mark of how the principle could successfully augment the wealth of a single nation, it is far too soon to guess how the prosperity of all nations will be increased by a full-scale extension of the principle internationally. In fact that process has hardly begun.

That may be why it was generally expected that the meeting last week in Uruguay of GATT's seventy-nine members would end in failure: the notion that free trade creates economic resources is widely disbelieved. But there was a surprise. In the event, the meeting accomplished most of what was expected of it. There are to be new negotiations on the tariffs by which some countries seek to protect domestic industries. (GATT's rules at present do not outlaw tariffs, but do require that tariffs should not discriminate between competing suppliers and that, eventually, they should melt away.) More important, there are to be negotiations on agriculture (which offers Europe's best hope of shedding its cumbersome Common Agricultural Policy), on trade in services (such as insurance policies) and on the protection of intellectual property.

The credit for this agreement rests with the United States, which has freely used the threat that the US Congress would thrust a slew of protectionist legislation on the administration if the meeting in Uruguay flopped. But the inevitable protests at "dollar imperialism" that will now be made should be scorned: US salesmen will indeed benefit if the planned negotiations succeed, but so too will the salesmen of other countries. Adam Smith, if he were still alive, would say that trade is not a zerosum game.

None of this implies that the time has come to celebrate; years of negotiations about details lie ahead. Some of the issues yet to be decided have vital importance for the technical community, not least the issue of what is grandly called intellectual property, which meant copyrights in printed books in Adam Smith's time and now means patents and designs as well. The United States was entirely right last week to argue that the international extension of the doctrine of the division of labour requires a similar extension of the principle that innovations (and inventors) deserve protection from pirates.

The snag is that even nationally, this right is not absolute; many industrialized countries reserve the right to grant compulsory licenses for drugs they consider to be socially important, while a wide group of governments (the beneficiaries of the Paris amendment of the Berne Copyright Convention) has the right to assign others' copyrights if they consider that justified in the interests of education or research. As in other arguments, each side has a case. Just where to draw the line is certain to perplex
GATT in the years ahead.

The predictable quarrels about intellectual property will be suffused in part with the other perennial problem in GATT: the economic imbalance between the industrialized and the developing world. In principle, the economic division of labour should make each more prosperous, but there is nothing in Adam Smith to legislate for the abolition of even relative poverty. But the developing world justly complains that even under the present version of GATT, industrial members are far too active in the protection of their own industries against imports from poor countries. The notious Multi-Fibre Agreement (an agreed exception to GATT rules) keeps rich workers employed in textile factories when they might be making computers instead, at the expense of their compatriot consumers and of would-be textile workers abroad. Is it any wonder that the latter should turn to piracy? And is there a chance that, in the negotiations that lie ahead, the industrialized nations will see the logic of the trade-off they must make between the legitimate demand for protection for their innovations and the improper protection they at present secure for textiles, shipbuilding, steel and other commodities at the cost of impoverishing developing countries that could make them more cheaply?

\section{Fireworks at Yale}

\section{Yale University, in the best traditions, seems to have found itself a firebrand for a president.}

THE inauguration at the weekend of Benno C. Schmidt as the new president of Yale was predictably a lively occasion. At 42, Schmidt is young as these appointments go, and while his attainments at Columbia as a constitutional lawyer are as distinguished as his academic colleagues would expect, he also has something of a reputation as an accomplished performer on television. His inaugural address was an extended version of a brief intervention at the Harvard ceremonies two weeks earlier: universities' social function includes irreverence, which institutions elsewhere (but especially governments) detest and are forever trying to subborn. Schmidt deplored the way that civil servants exercise discretion over the visits of foreign scholars, the way in which a "tide of conformity and fear" menaces learning in the public schools of the United States, and the way in which academic communities themselves are responsible for "assaults on intellectual freedoms that shame their traditions of liberty".

It is stirring stuff, but unfortunately true as well. The question Schmidt ducked at the weekend is whether, and if so how, present constraints on the freedom of universities and other academic institutions are avoidable, or curable. As with charity, the place to start is at home, which in Schmidt's case is a good place. Yale may have a reputation for turning out bankers, but there is nothing wrong in that, while the quality of its undergraduate education and of its research community are generally admired. If Yale has an identifiable fault, it is that its administration is rather more powerful relative to academic interests than it might be.

To the extent that the academic freedom of an academic institution must be a function of the degree to which its academics function as self-starting well-springs of academic policy, there is a case for making sure that, in the last resort, it is academics who call the tune. Most institutions need to be edged in this direction.

The fear that academic self-determination is a licence for academic indecision is, in reality, the opposite of the truth: Rights engender responsibilities, especially when the education of the young is a common objective. But Schmidt clearly believes that it is still possible for a university president to give his institution a sense of direction and thus a greater degree of independence. It will be interesting to see how his good speeches become reality. 